\title{
Cost and Time Overruns in Building Projects Procured Using Traditional Contracts in Nigeria
}

\author{
Dele S. Kadiri ${ }^{1} \&$ Babajide O. Onabanjo ${ }^{2}$ \\ ${ }^{1}$ Department of Quantity Surveying, Obafemi Awolowo University, Ile-Ife, Nigeria \\ ${ }^{2}$ Department of Architecture, Obafemi Awolowo University, Ile- Ife, Nigeria \\ Correspondence: Dele S. Kadiri, Department of Quantity Surveying, Obafemi Awolowo University, Ile-Ife, \\ Nigeria. Tel: 234-803-570-1241. E-mail: deleskadiri@yahoo.com
}

Received: August 2, 2017

doi:10.5539/jsd.v10n5p234
Accepted: September 5, $2017 \quad$ Online Published: September 29, 2017

URL: https://doi.org/10.5539/jsd.v10n5p234

\begin{abstract}
The traditional contract procurement system is reported to be the most preferred in Nigeria for the execution of construction projects. However, the system has been criticised to be ineffective in terms of both cost and time performances. Owing to scanty empirical evidence to support this claim, this study assessed cost and time overruns in building projects executed in Nigeria using the system. Schedule and cost data of building projects were accessed from randomly selected frontline quantity surveying firms in the study area. These comprised schedule data on 51 public and 41 private building projects as well as cost data on 42 public and 33 private building projects. The data were analysed using frequency, percentage and mean. The findings from the study revealed that both public and private building projects executed in the study area using traditional contract system experienced cost and time overruns to varying degrees. However, the system was more effective in terms of cost performance than time performance.
\end{abstract}

Keywords: building, cost overrun, Nigeria, time overrun, traditional contract

\section{Introduction}

The major feature of the traditional contract procurement method is the separation of design from construction (Babatunde, Opawole and Ujaddugbe, 2010). Adenuga (2013) opined that under the traditional contract method, consultants (Architects, Engineers and Quantity Surveyors) are responsible for the design, costing and supervision of a project on behalf of the client while a contractor is responsible for the construction work on site. Dada (2013) affirmed that the traditional contract method had its foundation in the doctrine of division of labour propounded by Adams Smith. The author claimed that the doctrine was premised on the understanding that division of labour promotes specialisation, expertise and productivity.

Shanmugapriya and Subramanian (2013) defined cost overrun as the difference between original cost estimate of a project and actual construction cost on completion. This implies that cost overrun is the amount of money spent over what was plaaned or intended. Similarly, the authors defined time overrun as the extension of time beyond planned completion date traceable to the contractor. Conversely, Bentil, Nana-Addy, Asare and Fokuo-Kusi (2017) defined cost overrun as the change in contract amount divided by the original contract award amount converted to percentage for ease of comparison. In other words, cost overrun is the percentage difference in cost between the final construction cost of a project and the contract award amount. Moreover, the authors opined that cost overrun can also be called cost escalation, cost increase or budget overrun. Ahbab (2012) affirmed that cost overun occurs when the actual cost of a project is more than the estimated cost. Similarly, that time overrun occurs when a project is finished later than the original estimated time. Vaardini and Subramarian (2015) observed that all projects regardless of size and complexity are burdened by uncertainties in deadlines.

Over the years, there have been insinuations that the traditional contract procurement system has not performed satisfactorily in terms of both cost and time. Dada (2013), for example, suggested that the traditional contract method may only succeed in giving a guarantee of certainty of initial cost. Ameh and Odusami (2007) believed that inflation or escalation of contract sum, amongst others, was a common phenomenon of traditional contracts. Tsai and Chi (2009) also alleged that traditional constracts were usually bidded low to secure award with the intention of hiking the cost later through loopholes in contract documents. Emanating from the above claims, it 
became necessary to investigate the cost and time performance of building projects executed in Nigeria using traditional contract system. The need is justifed going by the claim that this procurement system is the one which is most utilised in Nigeria (Idoro, 2007). It was therefore from the foregoings that this study assessed the building projects executed in Nigeria using traditional contracts with a view to ascertaining their cost and time performances.

\section{Overview of Cost and Time Overruns in Construction Projects}

Ojo, Adeyemi and Fagbenle (2006) reported that the traditional contract procurement has been widely criticised as an ineffective method because it often involves time and cost overruns on construction projects. Several researches have investigated the issue of cost and time overruns of construction projects around the world. Majority of these studies focused on either the factors influencing cost and time overruns or their effects on construction projects. There are however few studies on the quantitative analysis of cost and time overruns in construction projects let alone on public and private building projects. Among the few attempts are the works of Bentil et al. (2017), Prajapati (2016), Ahbab (2012), Memon et al. (2012), Amen et al. (2011) and Endut et al. (2005).

Bentil et al. (2017) investigated the level of existence and impact of cost and time overruns of building projects in Ghana with a view to minimizing them. The study involved the use of questionnaire survey to elicit data from Quantity Surveyors, Architects and Project Managers in client, contracting and consulting orgainsations in the study area. A total of 120 questionnaires were administered out of which 89 valid responses were retrieved and analysed. The findings of the study revealed that cost overrun existed in $40 \%$ of building projects in Ghana. Besides, public projects were shown to have $75 \%$ cost and $146 \%$ time overruns, on the average. Similarly, private building projects had $34 \%$ cost and $77 \%$ time overruns. From the study, it was therefore concluded that private projects performed better than public projects in the study area in terms of both cost and time overruns.

The study of Prajapati et al. (2016) was an assessment of the causes and effects of cost overrun on construction projects in India. The study was a case study of 34 public school buildings. Structured questionnaires were administered on 27 respondents from client, consulting and contracting organisations in the study area. From the study, it was found that cost overruns ranged between zero and $120 \%$ of contract amounts. It was however concluded that the average cost overrun in school buildings was between 10 and $30 \%$. It was also concluded that cost overrun decreased with increase in contract amount.

Ahbab (2012) investigated cost and time overruns in construction projects in Cyprus. The study was a case study of 28 large infrastructure projects funded by international banks in developing countries between 2000 and 2010 . The banks were the World Bank (WB), African Development Bank (AFDB) and Asian Development Bank (ADB). Data for the study were accessed from the databases of the banks. The projects comprised new works, reconstruction and improvement and cost and time overruns on the projects ranged from 13 to $32 \%$.

Memon et al. (2012) focused on time and cost performance of construction projects in Southern and Central Regions of Malaysian Peninsular. From the study which was based on questionnaire survey, it was reported that $92 \%$ of the projects investigated overran their time schedules while $89 \%$ of the projects experienced cost overrun. It was however concluded that both cost and time overruns on the projects were 5-10\%.

The study of Ameh and Osegbo (2011) was focused on the relationship between time overrun and labour productivity in construction sites in Nigeria. The study was based on questionnaire survey of 43 technical and management staff of medium and large scale construction firms in Lagos State, Nigeria. The construction firms were randomly sampled from the list of the Federation of Construction Industry (FOCI) in Nigeria. The data collected were analysed using frequency, mean score, regression analysis and factor analysis. From the study, it was reported that most projects executed in the study area experienced $51 \%$ time overrun.

Endut et al. (2005) reported on cost and time overruns of projects in Malaysia. The study which was focused on public and private sector projects was aimed at developing a system of risk management to proactively minimize cost and time overruns. From the findings of the study, it was concluded that cost overrun ranged from $-80.3 \%$ to $80.76 \%$ with an average of $2.08 \%$. Similarly, time overrun ranged from $-19.3 \%$ to $440 \%$ with an average of $49.71 \%$.

Ismail (2014) also reported on the findings of other studies on construction cost and time overruns as shown on Table 1 below. 
Table 1. Summary of cost and time overruns in construction projects

\begin{tabular}{|c|c|c|c|c|c|}
\hline $\mathbf{S} / \mathbf{N}$ & Author(s) & Study Area & $\begin{array}{l}\text { Cost Overrun } \\
(\%)\end{array}$ & $\begin{array}{l}\text { Time Overrun } \\
(\%)\end{array}$ & Project Type \\
\hline \multirow{2}{*}{1} & \multirow{2}{*}{ Bentil et al. (2017) } & \multirow{2}{*}{ Ghana } & 75 & 146 & Public projects \\
\hline & & & 34 & 77 & Private projects \\
\hline 2 & Prajapati (2016) & India & $10-30 \%$ & & Public school building projects \\
\hline 3 & Ahbab (2012) & $\begin{array}{l}\text { Developing } \\
\text { countries }\end{array}$ & $13-31 \%$ & & $\begin{array}{l}28 \text { Large infrastructure projects } \\
\text { funded by WB, AFDB \& ADB }\end{array}$ \\
\hline 4 & Memon et al. (2012) & Malaysia & $5-10 \%$ & $5-10 \%$ & Construction projects \\
\hline 5 & Ameh et al. (2011) & Nigeria & - & $51 \%$ & Telecom projects \\
\hline 6 & Endut et al.(2005) & Malaysia & $2.08 \%$ & $49.71 \%$ & Public \& pivate sectors projects \\
\hline \multirow{2}{*}{7} & \multirow{2}{*}{ Love et al. (2013) } & \multirow{2}{*}{ Australia } & $244 \%$ & - & Construction projects \\
\hline & & & $109 \%$ & - & Civil projects \\
\hline 8 & $\begin{array}{l}\text { Danso \& Antwi } \\
(2011)\end{array}$ & Ghana & & $\begin{array}{l}82 \% \text { in } 35-55 \% \\
\text { of projects }\end{array}$ & Telecom Towers \\
\hline 9 & $\begin{array}{l}\text { Amu \& Adesanya } \\
(2011)\end{array}$ & Nigeria & $53.2 \%$ & $46.1 \%$ & Civil engineering projects \\
\hline 10 & $\begin{array}{l}\text { Bhargara et al. } \\
(2010)\end{array}$ & India & $57 \%$ & $90 \%$ & Highway projects \\
\hline 11 & Zujo et al. (2010) & $\begin{array}{l}\text { Bosnia \& } \\
\text { Herzegoniva }\end{array}$ & $6.84 \%$ & $11.55 \%$ & Building projects \\
\hline 12 & Moura et al. (2008) & Portugal & $12 \%$ & $40 \%$ & Construction projects \\
\hline 13 & $\begin{array}{l}\text { Omoregie } \quad \& \\
\text { Radford (2006) }\end{array}$ & Nigeria & $14 \%$ & $188 \%$ & Infrastructure projects \\
\hline
\end{tabular}

The foregoing overview reveals that although several studies have been reported in literature, scanty attempts have been made to compare cost and time overruns in public and private sectors projects let alone building projects. Besides, the procurement systems used for the execution of the projects reported were not identified. Consequently, this study was undertaken to assess the cost and time overruns of public and private building projects executed in Nigeria using traditional contract system with a view to comparing their performances. Assessment of the causes and effects of or the factors influencing cost and time overruns were not covered in this study.

\section{Method}

The study population for this study was all the consulting firms of Quantity Surveyors in Nigeria being the custodians of the commercial tender documents, like bills of quantities, for building contracts. Secondary data were used for this study. Cost and schedule data on public and private building projects executed using traditional contract procurement method were thus obtained from 27 frontline consulting firms (those above 10 years of establishment) of Quantity Surveyors in the study area. A structured questionnaire was used to collect schedule and cost data on executed building projects from the responding firms which were randomly selected. The secondary data collected were planned and actual durations as well as contract sums and completion costs of public and private building projects executed by the responding firms. In all, schedule data were collected for 92 projects comprising 51 public and 41 private building projects. Similarly, cost data for 85 building projects were received, 52 on public and 33 on private buildings. The questionnaire also elicited demographic data from the respondents. These were number of building projects handled by respondents in the last five years, academic and professional qualifications as well as years of experience in the construction industry. The data obtained were analysed using frequency counts, percentage and mean. 


\section{Results and Discussion}

Table 2 shows that all the respondents possessed relevant academic qualifications required of quantity surveyors in Nigeria. Similarly, $85.2 \%$ of the respondents possessed requisite professional registrations of the relevant bodies in charge of quantity surveying training and practice in the country. The remaining $14.8 \%$ of the respondents were graduate members who have passed professional examinations but were still waiting to be inducted as full members of the profession. With regard to work experience, none of the respondents had worked for less than 12 years, on the average, in the Nigerian construction industry in one capacity or the other.

Table 2. Profiles of respondents

\begin{tabular}{|c|c|c|c|c|}
\hline Profile & & Frequency & \multicolumn{2}{|c|}{ \% of Total } \\
\hline \multicolumn{5}{|l|}{ Academic Qualification } \\
\hline Diploma & & 12 & \multicolumn{2}{|c|}{44.5} \\
\hline B.Sc./B.Tech. & & 8 & \multicolumn{2}{|c|}{29.6} \\
\hline M.Sc./M.Tech. & & 6 & \multicolumn{2}{|c|}{22.2} \\
\hline Ph.D & & 1 & \multicolumn{2}{|c|}{3.7} \\
\hline Total & & 27 & \multicolumn{2}{|c|}{100.0} \\
\hline Professional Qualification & & Frequency & \multicolumn{2}{|c|}{ \% of Total } \\
\hline MNIQS & & 19 & \multicolumn{2}{|c|}{70.4} \\
\hline FNIQS & & 2 & \multicolumn{2}{|c|}{7.4} \\
\hline MRICS & & 2 & \multicolumn{2}{|c|}{7.4} \\
\hline FRICS & & 0 & \multicolumn{2}{|c|}{0.0} \\
\hline Probationers & & 4 & \multicolumn{2}{|c|}{14.8} \\
\hline Total & & 27 & \multicolumn{2}{|c|}{100} \\
\hline \multicolumn{5}{|l|}{ Years of Experience } \\
\hline Interval & Midpoint(x) & Frequency (f) & $\mathbf{F x}$ & \% of Total \\
\hline $0-5$ & 2.5 & 3 & 7.5 & 11.1 \\
\hline $5-10$ & 7.5 & 9 & 67.5 & 33.3 \\
\hline $10-15$ & 12.5 & 5 & 62.5 & 18.5 \\
\hline $15-20$ & 17.5 & 7 & 122.5 & 26.0 \\
\hline $20-25$ & 22.5 & 0 & 0.0 & 0.0 \\
\hline $25-39$ & 27.5 & 3 & 82.5 & 11.1 \\
\hline Total & & 27 & 342.5 & 100 \\
\hline
\end{tabular}

Mean $=12.7$ years

Table 3 shows the time overrun of public building projects executed using traditional contracts in the study area. The Table was summarized from 51 schedule data collected from the responding firms. The Table indicates that all the projects overran the agreed completion schedules. However, more than half $(58.8 \%)$ of the number of projects were completed with an average of $10 \%$ time overrun. Moreover, $82.3 \%$ of the projects had an average of $20 \%$ time overruns. Overall, public building projects experienced an average of $26.9 \%$ time overrun. These findings compared well with those reported by Zujo et al. (2010) cited inIsmail (2014 for building projects executed in Bosnia Herzegovina which had $11.55 \%$ time overrun. The results however show that time overrun in public building projects in Nigeria fared better than what the case was in Ghana as reported by Bentil et al. (2017). That study reported that public projects in Ghana suffered an average time overrun of $146 \%$. 
Table 3. Time overrun in public building projects

\begin{tabular}{ccccc}
\hline Interval (\%) & Midpoint(x) & Frequency (f) & Fx & \% of Total \\
\hline $0-20$ & 10 & 30 & 300 & 58.8 \\
$20-40$ & 30 & 12 & 360 & 23.5 \\
$40-60$ & 50 & 2 & 100 & 3.9 \\
$60-80$ & 70 & 3 & 210 & 6.0 \\
$80-100$ & 90 & 2 & 180 & 3.9 \\
$100-120$ & 110 & 2 & 220 & 3.9 \\
Total & & $\sum \boldsymbol{f}=\mathbf{5 1}$ & $\sum \boldsymbol{f} \boldsymbol{x}=\mathbf{3 4 2 . 5}$ & $\mathbf{1 0 0 . 0}$ \\
\hline
\end{tabular}

Mean $=26.9 \%$

For private building projects, Table 4 (summary of 41 schedule data collected from respondents) shows the time performance of projects executed in Nigeria using traditional contract system. The Table indicates that $68.3 \%$ of the projects experienced an average of $10 \%$ time overrun. Similarly, $85.4 \%$ of the projects had an average of $20 \%$ time overrun. Overall, private building projects suffered a time overrun of $20.2 \%$. It is instructive to note that these findings show an improvement over the time performance (26.9\%) of public projects executed in the study area. The reason that may be advanced to be responsible for this is the perceived impact of bureaucracy associated with public decision making. However, the findings show a remarkable improvement when compared with private projects executed in Ghana. Bentil et al. (2017) reported average time overrun of $77 \%$ for private projects in Ghana. The same goes for $49.71 \%$ time overrun in private sector projects reported by Endut et al. (2009).

Table 4. Time overrun in private building projects

\begin{tabular}{ccccc}
\hline Interval (\%) & Midpoint(x) & Frequency (f) & Fx & \% of Total \\
\hline $0-20$ & 10 & 28 & 300 & 58.8 \\
$20-40$ & 30 & 7 & 360 & 23.5 \\
$40-60$ & 50 & 5 & 100 & 3.9 \\
$60-80$ & 70 & 0 & 210 & 6.0 \\
$80-100$ & 90 & 1 & 180 & 3.9 \\
$100-120$ & 110 & 0 & 220 & 3.9 \\
Total & & $\sum \boldsymbol{f}=\mathbf{4 1}$ & $\sum \boldsymbol{f x}=\mathbf{8 3 0}$ & $\mathbf{1 0 0 . 0}$ \\
\hline
\end{tabular}

Mean $=20.2 \%$

With regard to cost overrun, Table 5 (summary of 52 cost data received from respondents) shows the performance of public building projects executed in Nigeria using traditional contract system. The findings indicate that $61.5 \%$ of the projects experienced average cost overrun of $10 \%$ while $92.3 \%$ suffered average cost overrun of $20 \%$. Overall, public building projects experienced average cost overrun of $9.5 \%$. These results show that comparatively, public projects performed better in cost overrun $(9.5 \%)$ than a time overrun $(26.9 \%)$ in the study area. However, the findings compared well with public building projects executed in India with cost overrun of $10-30 \%$ as reported by Prajapati (2016). The same goes for building projects executed in Bosnia Herzegovina with cost overrun of $6.84 \%$ (Zujo et al; 2010) cited in Ismail (2014). The findings however differed substantially from public projects executed in Ghana which were reported by Bentil et al. (2017) to have cost overrun of $75 \%$. The findings did not also agree with the claim that projects executed in developing countries suffer cost overrun due to the impact of corruption (Adam et al; 2014). The authors claimed that corruption added up to $10-30 \%$ of contract value to the cost overruns of projects funded by the World Bank. 
Table 5. Cost overrun in public building projects

\begin{tabular}{ccccc}
\hline Interval (\%) & Midpoint(x) & Frequency (f) & Fx & \% of Total \\
\hline $0-20$ & 10 & 32 & 320 & 61.5 \\
$20-40$ & 30 & 16 & 480 & 30.8 \\
$40-60$ & 50 & 3 & 150 & 5.8 \\
$60-80$ & 70 & 0 & 0 & 0.0 \\
$80-100$ & 90 & 1 & 90 & 1.9 \\
$100-120$ & 110 & 0 & 0 & 0.0 \\
Total & & $\sum \boldsymbol{f}=\mathbf{5 2}$ & $\sum \boldsymbol{f} \boldsymbol{x}=\mathbf{1 , 0 4 0}$ & $\mathbf{1 0 0 . 0}$ \\
\hline
\end{tabular}

Mean $=9.5 \%$

Similarly, Table 6 (summary of 33 cost data received from respondents) shows the cost performance of private building projects executed in the study area using traditional contract system. The findings indicate that $87.9 \%$ of the projects experienced an average of $10 \%$ cost overrun. Moreover, $97 \%$ of the projects experienced $20 \%$ cost overrun on the average. Overall, private projects experienced an average of $13 \%$ cost overrun. These findings are in contrast with those of time overruns. For time overruns, this study showed that private projects $(20.2 \%)$ were better managed than public projects $(26.9 \%)$. Conversely, for cost overruns, this study showed that public projects $(9.5 \%)$ had less overrun than private projects $(13 \%)$. However, the cost overrun for private building projects from this study also compared well with $6.84 \%$ reported by Zujo et al. (2010) for building projects executed in Bosnia Herzegovina. The findings however are in contrast with those of Bentil et al. (2016) which reported that private projects experienced 34\% average cost overrun in Ghana. The authors also concluded that private projects performed better in Ghana than public projects in both cost and time parameters.

Table 6. Cost overrun in private building projects

\begin{tabular}{lcccc}
\hline Interval (\%) & Midpoint(x) & Frequency (f) & $\mathbf{F x}$ & \% of Total \\
\hline $0-20$ & 10 & 29 & 290 & 87.9 \\
$20-40$ & 30 & 3 & 90 & 9.1 \\
$40-60$ & 50 & 1 & 50 & 3.0 \\
$60-80$ & 70 & 0 & 0 & 0.0 \\
$80-100$ & 90 & 0 & 0 & 0.0 \\
$100-120$ & 110 & 0 & 0 & 0.0 \\
Total & & $\mathbf{\Sigma f}=\mathbf{3 3}$ & $\mathbf{\Sigma f}=\mathbf{4 3 0}$ & $\mathbf{1 0 0 . 0}$ \\
\hline
\end{tabular}

Mean $=13.0 \%$

\section{Conclusions}

The investigation discussed in the paper relates to the cost and time overruns of building projects executed in Nigeria using traditional contract procurement system. It was carried out to provide empirical evidence for the performance of this procurement option in the study area. Cost and schedule data on the executed building projects using the system were obtained from frontline consulting firms of quantity surveyors. Analysis of the data indicates that both public and private building projects experienced cost and time overruns in the study area. It was also concluded that overall, public building projects performed better in cost overrun than private. Similarly, private building projects performed better than public building projects in time performance parameter. There is however the need for all project stakeholders to work together to improve on the performance of traditional contract system in terms of cost and time.

\section{References}

Adam, A., Josephson, P., \& Lindah, G. (2014). Implications of cost overruns and time delays on major public 
construction projects. Proceedings of the 19th International Symposium on the Advancement of Construction Management and Real Estate, 7-9 November 2014, Chongquig.

Adenuga, O. A. (2013). Comparison of the performance of traditional and direct labour methods of project procurement: A case study of some selected projects of Nigerian Army. Ethiopia Journal of Environmental Studies and Management, 6(1), 21-30.

Ahbab, C. (2012). An Investigation on time and cost overruns in construction projects. M.Sc. Thesis in Civil Engineering. Eastern Mediterranean University, Gazimagusa, North Cyprus.

Ameh, O. J., \& Odusami, K. T. (2007). Nigerian building professionals' ethical ideology and perceived ethical judgement. Construction Research Journal, 2(1), 32-42.

Ameh, O. J., \& Osegbo, E. E. (2011). Study of relationship between time overrun and productivity on construction sites. International Journal of Construction Supply Chain Management, 1(1), 56-67. https://doi.org/10.14424/ijcscm101011-56-67

Babatunde, S. O., Opawole, A., \& Ujaddugbe, I. C. (2010). An appraisal of project procurement methods in the Nigerian construction industry. Civil Engineering Dimension, 12(1), 1-7.

Bentil, E., Nana-Addy, E., Asare, E. K., \& Fokuo-Kusi, A. (2017). The level of existence and impact of cost and time overruns of building construction projects in Ghana. Civil and Environmental Research, 9(1), 36-46.

Dada, M. O. (2013). Analysis of conflict centers in projects procured with traditional and integrated methods in Nigeria. Journal of Construction Supply Chain Management, 3, 1-15. https://doi.org/10.14424/ijcscm301013-01-15

Endut, I. R., Akintoye, A., \& Kelly, J. (2005). Cost and time overruns of projects in Malaysia. Proceedings of the $2^{\text {nd }}$ Scottish Conference for Postgraduate Researchers of the Built and Natural Environment (PROBE) 16-17 November 2005, Glasgow Calidonia University.

Idoro, G. I. (2007). A Comparative study of direct labour and design-tender-construct procurement systems in Nigeria. Ph.D Thesis, Department of Building, University of Lagos, Akoka, Yaba, Lagos, Nigeria.

Ismail, I. B. (2014). Risk assessment of time and cost overrun factors throughout construction project life cycle. M.Sc, thesis Faculty of Civil and Environmental Engineering, Universiti Tun Hussein onn Malaysia.

Memon, A. H., Rahman, I. A., \& Azis, A. A. A. (2012). Time and cost performance in construction projects in Southern and Central Regions of Penisular Malaysia. International Journal of Advances in Applied Sciences, 1(1), 45-52. https://doi.org/10.11591/ijaas.v1i1.537

Memon, A. H., Rahman, I. A., Abdullah, M. R., \& Aziz, A. A. A. (2011). Time overrun in construction projects from the perspective of project management consultants (PMC). Journal of Surveying, construction and Property, 2(1), 54-67.

Ojo, S. O., Adeyemi, A. Y., \& Fagbenle, O. (2006). The performance of traditional contract Procurement in Housing Projects in Nigeria. Civil Engineering Dimensions, 2(2), 106-112.

Prajapati, S. K., Gupta, R., \& Pandey, M. (2016). Causes and effects of cost overrun on construction projects in Madhya Predesh. International Journal of Engineering Development and Research, 4(2), 1346-1350.

Shanmugapriya, S., \& Submanian, K. (2013). Investigation of significant factors influencing time and cost overruns in Indian construction projects. International Journal of Emerging Technology and Advanced Engineering, 3(10), 734-740.

Tsai, J., \& Chi, C. S. F. (2009). Influences of Chinese cultural orientations and conflict management styles on construction dispute resolving strategies. Journal of Construction Engineering Management, 135(10), 955-964. https://doi.org/10.1061/(ASCE)0733-9364(2009)135:10(955)

Vaardini, U. S., \& Subramanian, K. (2015). Identification of causes and impacts of time overrun in Construction Projects. International Journal of Applied Engineering Research, 10(19), 14253-14261.

Zujo, V., Car-Pusic, D., \& Brkan-Vejzovic, A. (2010). Contracted price overrun as contracted construction time overrun function. Technical Gazette, 17(1), 1-12.

\section{Copyrights}

Copyright for this article is retained by the author(s), with first publication rights granted to the journal.

This is an open-access article distributed under the terms and conditions of the Creative Commons Attribution license (http://creativecommons.org/licenses/by/4.0/). 